\title{
ARTICLE
}

\section{We need to talk to Martha}

\section{Or: The desirability of introducing simple adoption as an option for long-term foster children in The Netherlands}

\author{
mr. dr. M.J. Vonk \& dr. G.C.A.M. Ruitenberg*
}

\section{Introducing Martha}

Martha is four months old when her mother leaves her with child care services because her parents are separating and her mother is unable to take care of Martha by herself. At first Martha is placed in a short-term foster family, but once it becomes clear that it is very unlikely that her mother or father will be able to take care of her in the (near) future, she is transferred to a long-term foster family. This family is her home for the next 17 years. A couple of weeks before her eighteenth birthday she starts to worry. What will happen when she becomes an adult? She is not yet ready to live by herself. Will her foster parents tell her to leave? Martha has no contact with her original mother and has only very recently traced her biological father. Contact with him is loose but pleasant. Her foster parents are the most important people in her life, next to her friends and her boyfriend. Her foster parents tell her that she can stay until she is ready to live by herself and that she will always be welcome in their family. Still she worries; what if she has a serious car accident? Only 'real' family can visit her in the hospital or make decisions on her behalf, and her foster parents are not 'real' family. Martha's story is one of eighteen stories in a book of interviews with eighteen foster children on the brink of adulthood. ${ }^{1}$ Martha is not the only one who worries about her legal relationship with her foster family when she is an adult. This is one of the reasons the Dutch Government Committee on the reassessment of parenthood (hereafter: the Committee) proposed to introduce simple adoption for long-term foster children in 2016. ${ }^{2}$ This new form of adoption would forge a life-long legal bond between the foster child and foster family without severing the existing legal bond between the child and his/her original parents and their family. In the wake of this report research has

* Machteld Vonk is associate professor at the Amsterdam Center for Family Law of the Private Law Department at VU University Amsterdam. Geeske Ruitenberg is assistant professor at the Amsterdam Center for Family Law of the Private Law Department at the VU University Amsterdam.

1 F. Juffer, L. Popma, M. Steenstra (red.), 18x18 Pleegkinderen op de drempel, Eindhoven: Lecturis 2016.

2 Government committee on the reassessment of parenthood, Child and parents in the 21st century (English summary), The Hague, 2016 (hereafer: the 2016 report). Original publication in Dutch: Staatscommissie Herijking Ouderschap, Kind en ouders in de 21ste eeuw, Den Haag, 2016. 
been done by the authors as to the desirability and feasibility of the introduction of simple adoption. ${ }^{3}$

\section{A brief overview of the Dutch child protection measures or how did Martha end up with her foster family?}

A child may be placed in a foster family if their parent(s) is/are unable to take care of the child for a short or longer period of time. This can be a voluntary placement with a family member or a placement in the context of a child protection measure. If a child is placed in a foster family through a child protection measure there is a choice between placement in the (extended) family or social environment of the child (with grandparents, older siblings, aunts or uncles, school friends etc.) or placement with a registered approved foster family. ${ }^{4}$ There is a preference in international law for placement within the extended family context, but that is not always possible. ${ }^{5}$ The basis for a placement in a foster family in the context of a child protection measure is a supervision order in combination with an out-of-home placement order. ${ }^{6}$ These are both temporary measures that can be ordered for a maximum of one year at a time. The aim of these measures is to support parents and children in such a way that the parents can in due course resume their full parental role in a manner that is not harmful for the child. ${ }^{7}$ Parents will retain parental responsibilities during these measures, but they will be limited in the use of them. Clearly, under an out-of-home placement order they are no longer in the position to determine where the child lives, but they must be involved in important decisions about the child's well-being, schooling, medical treatment etc. ${ }^{8}$ There are some exceptions where the court can allow the gecertificeerde instelling $(\mathrm{GI})^{9}$ to act on the child's behalf without the parents' consent, for instance when the parents refuse to consent to medical treatment of the child. ${ }^{10}$

Since the aim of the supervision order and the placement in a foster family is to ensure a safe return of the child to its family by assessing the parents' parenting skills and the extent to which these can be improved (if necessary) within a reason-

3 M. Vonk, W.D. de Haan, C.G. Jeppesen de Boer and G.C.A.M. Ruitenberg, Eenvoudige adoptie van pleegkinderen, Den Haag: Boom Juridisch, 2020 (hereafter: WODC Report 2020).

4 K.A.M. van der Zon, Pleegrechten voor kinderen: Een onderzoek naar het realiseren van de rechten van kinderen die in het kader van een ondertoezichtstelling in een pleeggezin zijn geplaatst (diss. Leiden), Den Haag: Boom Juridisch 2020 (hereafter: Van der Zon 2020).

5 United Nations Guidelines for the Alternative Care of Children, e.g. §60. Van der Zon 2020, p. 113125.

$6 \quad$ Art. 1:255 lid 1 BW and Art. 1:265b BW.

7 Art. 1:255 lid 1 sub b BW. See also Van der Zon 2020, p. 163-166.

8 Recent prejudicial question from District Court The Hague to the Supreme Court: ECLI:NL:RBDHA:2020:9018, Rechtbank Den Haag, 14 September 2020, C/09/595188, ECLI:NL:RBDHA: 2020:10397, Rechtbank Den Haag, 16 October 2020, C/09/595188 and ECLI:NL:PHR:2021:57, Parket bij de Hoge Raad, 22 January 2021, 20/03359 (voorstel beantwoording vragen).

9 Gecertificeerde Instelling is the term for Youth Care Agency since the introduction of the new law, it literally means 'Licensed Agency'.

10 Art. 1:265h BW and Art. 1:265e BW. 
able period of time, these orders cannot stay in place indefinitely. ${ }^{11}$ At some point, the child deserves to know where it will grow up, with the original family or with the foster family. Essential in this context is the concept of the aanvaardbare termijn; the decision whether a child's future lies with the parents or with a foster family has to be made within a time frame that is acceptable in terms of the child's person and development (Art. 1:266 lid 1 BW). What is an acceptable time frame is a decision that has to be made within the context of the case and in particular with regard to the needs of the child concerned. Generally, the acceptable time frame is considered to be shorter for younger children than for older children. ${ }^{12}$ Once this period of time has passed, the child is entitled to certainty about its future and a decision has to be made whether the child will return to its parents or whether this is not in the child's interest and the parents' parental responsibilities needs to be terminated and attributed to either the GI or the foster parent(s). In practice, it is usually the GI who is attributed guardianship over the child after termination. Termination of the parents' parental responsibilities also signals the end of the supervision order and the out-of-home placement order.

If the foster parents want to take on more responsibility for their foster child, they can obtain foster parent guardianship or they can apply for full adoption with the court. ${ }^{13}$ For both measures the termination of parental responsibilities of the original parents is a prerequisite. There are a number of important differences between foster parent guardianship and full adoption. For instance, foster parent guardianship means the foster parents will obtain guardianship over the child, but the child remains legally part of their original family. This means that when the foster child reaches the age of majority (eighteen), foster parent guardianship ends by operation of law and legal ties between foster child and foster family end. Legal family ties with the original family do however remain. With (full) adoption by the foster parents all legal ties with the original family are severed, but lifelong legal family ties between the child and the foster parents and their family are established. Moreover, the adoptive parents gain parental authority over the child as a result of the (full) adoption. There is no possibility under current Dutch law to maintain legal family ties with both the original and the foster family once the foster child becomes an adult.

In 2016 the Dutch Government Committee on the reassessment of parenthood (hereafter: the Committee) proposed the introduction of a form of adoption that would forge legal family ties with the foster family while at the same time leaving the legal family ties with the original parents intact. ${ }^{14}$ The Committee refers to this new form of adoption as 'simple adoption' (eenvoudige adoptie). ${ }^{15}$ The Committee

11 Kamerstukken II 2008/09, 32 015, nr. 3, p. 4 and further. See also Savornin Lohman et al., Met recht onder toezicht gesteld, Evaluatie herziene OTS-wetgeving, Utrecht, 2000 and Slot et al., 909 zorgen. Een onderzoek naar de doelmatigheid van de ondertoezichtstelling, Amsterdam: Vrije Universiteit 2002 (hereafter: Slot et al 2002).

12 Kamerstukken II 2008/09, 32 015, nr. 3 (MvT), par. 5.2.

13 Art. 1:295 BW and further (guardianship) and Art 1:227 BW and further (adoption).

14 The 2016 report, p. 435.

15 Ibid. 
states that the advantage of simple adoption for the child would be that their factual situation would be optimally protected by forging legal ties with the foster parents who are actually raising the child without severing the legal ties with the child's original parent(s). ${ }^{16}$ This would on the one hand create a legal situation that is in alignment with the factual situation ${ }^{17}$ and on the other hand affirm that both the original family and the foster family are part of the child's identity. In this context we will address two issues in this article. First of all, who has decision-making power in the different situations where a foster child lives with a long-term foster family? Secondly, would simple adoption attribute to recognition of the child's identity as belonging to both the family of origin as well as the foster family?

\section{Who is responsible or who makes decisions about Martha's care and future?}

First of all, when talking about decision-making power, we need to distinguish between different situations and the different actors involved in these situations. We can distinguish five different possible situations in long-term foster care:

1 The child lives with a long-term foster family on a voluntary basis. The parents have parental responsibilities, and there is no child protection order.

2 The child lives with a long term-term foster family on the basis of successive supervision and out-of-home placement orders. The parents still have parental responsibilities. This is not the preferred scenario of the legislator, ${ }^{18}$ but it does happen in practice. ${ }^{19}$

3 The child lives in a long-term foster family; the GI has been awarded guardianship after the parents' parental responsibility was terminated.

4 The child lives in a long-term foster family and the foster parents have been awarded foster parent guardianship.

5 The long-term foster parents have adopted the foster child. ${ }^{20}$

\subsection{Long term voluntary foster care}

In case of long-term voluntary foster care the child's parents retain parental responsibilities and can make all the relevant decisions, with one exception: once the child has been living with the foster parents for more than a year, the parents cannot end the placement without the foster parents' or the judge's consent. ${ }^{21}$ Foster parents ${ }^{22}$ can take on the voluntary care of a child without any involvement of the

16 Ibid., p. 436.

17 J. Palacios, S. Adroher, D.M. Brodzinsky, H.D. Grotevant, D.E. Johnson, F. Juffer, L. Martínez-Mora, R.J. Muhamedrahimov, J. Selwyn, J. Simmonds \& M. Tarren-Sweeney, 'Adoption in the service of child protection: An international interdisciplinary perspective', Psychology, Public Policy, and Law, 2019 vol. 25, no. 2, p. 57-72.

18 Kamerstukken II 2008/09, 32 015, nr. 3, p. 4 and further.

19 CBS, 30 oktober 2020, Jeugdbeschermingstrajecten (consulted 24 March 2021).

20 Technically this is no longer long-term foster care, but since this is relevant in the context of this paper, we will discuss it anyway.

21 Art 1:253s BW.

22 Technically, they are not foster parents if they do not have a contract with a foster care provider (Art. 1.1. Jeugdwet). 
authorities once the child is older than six months. ${ }^{23}$ However, if they want to obtain help and financial support from a foster care provider, they need to enter into a foster contract with this provider. ${ }^{24}$ This foster contract contains rules on the care and upbringing of the child by the foster parents and the support they will receive from the foster care provider. ${ }^{25}$ In 2019 29\% of the children living with a foster family were placed on a voluntary basis. ${ }^{26}$

\subsection{Long-term foster care in the context of a supervision and an out-of-home place- ment order}

If a child is placed out-of-home with a foster family in the context of a supervision order, the child's parents retain their parental responsibilities, though they are substantially limited. ${ }^{27}$ Two actors, besides the foster parents and the parents, are involved in this situation, namely the GI and the foster care provider. The GI, in the person of the youth care worker, supports and supervises the parents and the foster child. The foster care provider, in the person of the foster care worker, supports and supervises the foster parents and the foster child. ${ }^{28}$ Decisions about the daily care of the child will generally be taken by the foster care provider and the foster parents (the framework for this has been included in the foster contract), if necessary in consultation with the GI and the parents. More important decisions about things, such as schooling and medical treatment, can only be made with the parents' consent, unless a judge has placed these decisions in the hands of the GI. ${ }^{29}$ If, for instance, the GI thinks EMDR treatment is necessary for the foster child to come to terms with traumatic events from the past, the parents need to consent to this treatment. If they do not consent, the GI can apply to the court for consent. Or if the GI wants to place the foster child in another foster family, when the child has been living with the current family for more than a year, the consent of the foster parents or the judge is required.$^{30}$ However, there is less clarity about the division of decision-making powers over the four actors involved (the parents, the GI, the foster care provider, and the foster parents) with regard to issues not so clearly regulated by law. In 2018 the Dutch Supreme Court answered a number of prejudicial questions relating to changes to existing contact arrangements between parents and children. ${ }^{31}$ And, more recently. prejudicial questions were asked about the division of responsibilities in the context of family holidays. ${ }^{32}$ The foster family in this case meant to take their foster child on a family holiday, but the parents did

In case of voluntary foster care for a child younger than six months, written consent of the child protection board (Raad voor de Kinderbescherming) is required (Art. 1:241 lid 3 BW). Criminal sanction can be taken if foster parents act in breach of this requirement (Aart. 442a Wetboek van Strafrecht).

24 Chapter 5 Jeugdwet.

25 Art. 5.2. lid 1 Jeugdwet.

26 Factsheet Pleegzorg 2019.

27 This concerned 22\% of the children living in a foster family in 2019. Factsheet pleegzorg 2019.

28 Jeugdzorg Nederland 2016, Pleegzorg: een gezamenlijke zorg. Landelijke handreiking Samenwerkingsafspraken Jeugdbescherming - Pleegzorgaanbieder, Versie 2.0, 1 januari 2016, p. 7.

29 Art. 1:265e BW.

30 Art. 1:265i BW.

31 Hoge Raad, 14 december 2018, ECLI:NL:HR:2018:2321.

32 Rechtbank Den Haag, 16 oktober 2020, ECLI:NL:RBDHA:2020:10397. 
not consent, so the GI applied to the court for consent. During this procedure a number of questions arose: Do foster parents need consent from the parents to take the foster child on a trip or holiday? Does it matter how long the trip is and whether the foster parents mean to take the child abroad? If consent of the parent is not required, do the foster parents need the GI's consent? These questions illustrate the complexity of the involvement of these four actors in this situation. ${ }^{33}$ Research shows that foster parents cannot always act quickly because they have to wait for parental consent. ${ }^{34}$ As stated before, a number of elements of the parents' parental responsibility can be transferred to the GI for the duration of the supervision and out-of-home-placement order. This concerns decisions about registration with a school, consent to medical treatment and the application for a residence permit. ${ }^{35}$ The GI also has the option to apply for a more temporary measure in case of specific medical treatment ${ }^{36}$ or in case of more urgent and far-reaching measures in view of an application for termination of parental responsibilities. ${ }^{37}$ The foster parents have no decision-making power under these circumstances, they do, however, have the obligation to raise the foster child in accordance with the rights and duties set out in Article 1:247 lid 2 BW, namely to take responsibility for and to promote the child's mental and physical well-being and the child's safety, as well as the development of the child's personality. This article also explicitly states that there is no room for mental abuse or physical violence of any sort in the care for the child. ${ }^{38}$

Given the fact that the aim of the supervisions order in combination with the outof-home placement is the return of the child to the original family as soon as this is feasible and safe for the child, it makes sense that the parents remain actively involved in decisions about the child. However, once it is clear that return to the original family is no longer feasible, this is a very complex state of affairs to leave in place for a long time. Prior to the legislative change in 2015 it was not unusual for supervision and out-of-home placement orders to last until the child turned eighteen. ${ }^{39}$ Since the new legislation was introduced in 2015 the idea is that it should be clear within a reasonable amount of time where the child's future lies and that the legal situation will be arranged accordingly. This perspectiefbesluit is one of the most invasive decisions in the lives of parents and children and there is discussion whether parents and children are involved in this decision as much as they

Research by Regioplan, Pleegouders over gezag en adoptie, Amsterdam, July 2015 (hereafter: Regioplan 2015), 2015, p. 17 shows that almost half of the foster parents involved in their study experience practical problems when the parents still have parental responsibility, because they are not allowed to sign relevant applications (such as for school, a bank account or passport) as guardian. They need the parent's signature for these applications. If the parent is unwilling to cooperate with the GI this is problematic.

34 Regioplan 2015, p. 17.

35 Art. 1:265e BW.

36 Art. 1:265h BW.

37 Art. 1:268 BW.

38 Art. 1:247 lid 2 BW also applies to those (such as foster parents) who do not have parental responsibilities but are taking care of a child or have guardianship over a child (Art. 1:248 BW). 
should be. ${ }^{40}$ Parents (and children) have no option under current law to contest this decision by the GI, despite the fact that it will influence the support offered by the GI. Once the GI has decided that the child cannot return home, the logical next step under Dutch law is to ask the court to terminate the parents' parental responsibilities. Subsequently, there are two options: Either the GI will become the child's guardian or the foster parents will become the child's guardian.

\subsection{Long-term foster care when the GI is the child's guardian}

Research shows that in $75 \%$ of the cases where parental responsibility has been terminated, guardianship is awarded to the GI. ${ }^{41}$ The biggest difference with the situation described under paragraph 3.2 is that the GI takes over the role of the parents where their decision-making capacity is concerned. The GI is now responsible for all decisions that concern the child. The parents still have a right to contact with the child and information about the child, unless this is contrary to the child's best interest. ${ }^{42}$ The role of the foster care provider and the foster parents does not change legally; neither of them is attributed with guardianship. Research shows that generally the communication between foster parents and the GI as guardian is satisfactory. Foster parents do, however, face practical problems because they have to wait for the GI's consent in its role as guardian, for instance when applying for a bank account or medical treatment. ${ }^{43}$ On the other hand, foster parents are happy that the GI remains involved as the organizer of contact between the parents and the foster child.

\subsection{Long-term foster care when the foster parents are the child's guardians}

Only in $12 \%$ of all cases of foster care (whether voluntary of not) do foster parents have foster parent guardianship. ${ }^{44}$ It is hard to obtain a clear picture how many long-term foster parents are awarded guardianship. The following numbers may give some confirmation of the suspicion that only a small portion of long-term foster parents actually become guardians. In 2019 the GI's guardianship over foster children ended in 1.410 cases, in 285 of these cases the GI's guardianship ended because the foster parents were attributed with foster parent guardianship, in 935 cases because the foster child turned eighteen and in 180 cases because the parents were reattributed with parental responsibility. ${ }^{45}$ Furthermore, of these 1.410 cases where the GI's guardianship ended, in 790 cases the GI had been the child guardian

40 B. Lateveer, 'Het opvoedbesluit', FJR 2020/41; N. van Cappeleveen \& K. van der Zon, 'Gezagsbeëindiging: het kind tegenover de ouder?', in: M.R. Bruning, K.F.M. Klep \& E.C.C. Punselie (red.), De invloed van 30 jaar Kinderrechtenverdrag in Nederland, Recht en Praktijk - Personen- en familierecht, deel 7, Deventer: Wolters Kluwer 2020; Raad voor Strafrechtstoepassing en Jeugdbescherming, Het perspectiefbesluit in de Jeugdbescherming, 2021.

41 Factsheet Pleegzorg 2019. For 49\% of the children living in a foster family in 2019, the parental responsibility of their parents had been terminated. In $75 \%$ of these cases the GI had been awarded guardianship and in $25 \%$ of these cases the foster parents.

42 Arts. 1:377a BW and 1:377c BW.

43 Regioplan 2015, p. 17-19.

44 Factsheet Pleegzorg 2019, p.3.

45 CBS, 30 oktober 2020, Jeugdbeschermingstrajecten (consulted 24 March 2021). 
for four years or more. ${ }^{46}$ It was the intention of the 2015 changes in the law, to make sure that legal and factual responsibility for a long-term foster child would be placed in the same hands. Clearly this has not happened. Research among foster parents indicates that some $80 \%$ of foster parents is aware of the possibility of foster parent guardianship and half of these foster parents have been asked whether they are willing to become the guardians of their foster child. ${ }^{47}$ Almost a quarter of these foster parents indicate that they want to become the guardians of their foster child, a quarter is not yet certain, a quarter does not want to and a quarter says that is not possible in their situation. ${ }^{48}$ The two main reasons these foster parents give for wanting to become their foster child's guardian is, on the one hand, that they want it to be extra clear for their foster children to feel they are part of the family and, on the other hand, that they want to be able to make important decisions about their foster children. ${ }^{49}$ The two main reasons who foster parent indicate they do not or are not sure whether they want to have guardianship are, on the one hand, that they value the intermediary role of the youth care worker between them and the original parents and, on the other hand, that foster parents are afraid of the fact that once they have guardianship they no longer have automatic support if the child develops behavioural problems in the future. ${ }^{50}$ Having guardianship means that, like any other parent, they are responsible for the child's well-being and will have to enlist help if the child needs it. ${ }^{51}$ Foster parents with guardianship who have entered into a contract with a foster care provider will retain their foster care allowance and a minimal number of one meeting per year with the foster care provider. ${ }^{52}$ The involvement of the GI, however, is terminated with the transfer of parental responsibilities/guardianship to the foster parents.

\subsection{Adoption in the context of foster care}

When a child has been living with the foster parents for a substantial amount of time and it has become clear that the child cannot return to its original parents, the possibility of adoption may be discussed. In practice, however, this rarely happens. ${ }^{53}$ The number of children that are adopted domestically is very limited and (full) adoption of foster children by their foster parents rarely occurs in the Netherlands. ${ }^{54}$ Adoption is only possible subject to strict conditions, partially because the legal ties between the child and the original parents are severed. ${ }^{55}$ For example,

46 Ibid.

47 Regioplan 2015, p. 20-21.

48 Ibid., p. 21-22.

49 Ibid., p. 22-23.

50 Ibid., p. 23.

51 Arts. 1:245 lid 2, 3 en 4 BW jo. 1:248 BW.

52 Art. 5.1 lid 1 Jeugdwet.

53 Regioplan 2015, p. 32: 4,6\% of the foster parents in this study indicate that they have been asked whether they would consider adoption of their foster child.

54 There are no statistics that focus on the adoption of foster children in particular, but the number of children adopted in the Netherlands has been very low for years (20-30 children). From CBS Statline: Adopties van 1957-2012, (https://opendata.cbs.nl/statline/\#/CBS/nl/dataset/80496NED/table?fromstatweb) follows that less than fifty children (born between 2000 and 2010) were adopted. It is unknow how many of them are foster child adoptions. 
the adoption must be in the interest of the child and it must be clear that the child has nothing more to expect from the original parents in their capacity as parents. ${ }^{56}$ There are also conditions concerning the child, the original parents and adoptive parents and their age. Moreover, the adoptive parents may not be the child's grandparents. ${ }^{57}$ The (legal) consequence of adoption is that the adopted child is given the same position with regards to the foster parents and their family as their own (biological) children. ${ }^{58}$ Because of this, a maintenance obligation arises, the child can inherit, the child can assume the family name and nationality of the adoptive parents and the adoptive parents obtain parental responsibilities. If there is contact between the child and the original parents at the time of the adoption order, the court may make a contact order. ${ }^{59}$ This means the child does in fact retain contact with the original parents. For a short period of time after the child becomes an adult, the child has the option to revoke the adoption. ${ }^{60}$ If an adoption is revoked, the original family ties are restored. ${ }^{61}$ Adoptive foster parents become responsible for maintaining and facilitating contact between the foster child and its original parents and also for arranging the care that the foster child needs. In the case of (full) adoption of the foster child, the foster parents (adoptive parents) become completely responsible for the child, because both the foster care allowance and the remaining foster care support cease to be available. Research shows that about $50 \%$ of the foster parents is aware of the fact that they can adopt their foster child when the parents' parental responsibility has been terminated. ${ }^{62}$ There is little to no after care available for adoptive parents and children.

\section{Simple adoption: a feasible option?}

At the instigation of the Dutch Parliament ${ }^{63}$ research was done in order to answer the question whether simple adoption, as it was proposed by the earlier mentioned Committee, is a feasible and desirable option for long term-foster children and their foster parents. ${ }^{64}$ In the eyes of the Committee, the advantage of simple adoption for the child lies in the fact that the foster child's factual situation would be optimally protected by forging legal ties with the foster parents who are actually raising the child without severing the legal ties with the child's original parent(s). ${ }^{65}$ The legal consequences of simple adoption would be the same as those of regular legal parental ties, which not only means that the child could have up to four legal parents, but also that all these parents would have a child maintenance obligation until the child turns 21 . Furthermore, the child would inherit from both the origi-

63 Brief aan Tweede Kamer, 22 March 2018, Kamerstukken II 333836 nr. 24.

64 This study resulted in theWODC Report 2020.

65 The 2016 Report, p. 436. 
nal parents and their families and the adoptive parents and their families. In case the child is no yet a Dutch national, it will acquire the Dutch nationality upon adoption if one of the adoptive parents is a Dutch national. The Committee notes that simple adoption may also have consequences for the child's family name, but does not propose any rules. Moreover, the Committee leaves the decisions about who will be attributed with parental responsibility with the judge.

In order to answer the question whether the introduction of simple adoption is desirable and feasible, the study consisted of a legal (comparative) component and an empirical component. The legal component consisted of a study of the current Dutch legal regulations surrounding long-term foster care and its problems, and a brief comparative legal study of systems that have a form of simple adoption, or considered introducing a form of simple adoption (France, Australia, Quebec and California). ${ }^{66}$ The empirical component consisted of questionnaires sent out to foster parents, and a number of in-depth interviews with a smaller group of foster parents and foster children from different regions and ages and some professionals and an expert meeting. The focus of the study was on full-time foster families who had been caring for a foster child for at least a year. The rest of this section will focus on the results of the empirical part of this study.

\subsection{Simple adoption from the perspective of foster parents (a survey)}

For the dissemination of the questionnaire, the study reached out to the 27 foster care organizations in the Netherlands, ${ }^{67}$ of whom 17 took part in the research by sending a link to a digital questionnaire to their long-term foster parents. The questionnaire was answered by 615 full-time foster parents, who had been caring for a foster child for at least a year $(N=603)$ or did so in the past five years $(N=12)$. The questionnaire contained questions about the current form of full adoption and the pros and cons of introducing a form of simple adoption. It was concluded from the results that a small majority of foster parents are not aware of the possibility of adopting their foster child. In total 560 foster parents said that that possibility had never been discussed with them and that they never asked questions about adoption themselves. ${ }^{68}$ A large majority of foster parents is unsure whether they should adopt their foster child or do not believe adoption of their foster child to be either possible or desirable. ${ }^{69}$ There is no consensus among the foster parents in the survey whether simple adoption should be introduced. A small majority prefers simple adoption to full adoption, but others are not sure or are altogether opposed to any form of adoption of foster children. ${ }^{70}$ Most foster parents, however, do see advantages in simple adoption, as opposed to full adoption. ${ }^{71}$ The advantage chosen most often is that the ties with the original parent(s) will remain intact, while at the of foster care, this part of the study will not be discussed in this article.

67 See Bijlage 3 of the WODC Report 2020 for a list of the organizations that took part.

68 WODC Report 2020, p. 80-81.

69 Ibid., p. 82-83.

70 Ibid., p. 84.

71 Ibid., p. 85. 
same time the foster child will feel a sense of belonging part in the foster family. The disadvantage chosen most often is that having three of four legal parents may lead to a rise in conflicts. ${ }^{72}$

The questionnaire subsequently contained a number of questions about the conditions for and consequences of a possible form of simple adoption. We will mention the most relevant elements and answers from the questionnaire. ${ }^{73} \mathrm{~A}$ majority of the foster parents believes that the foster child should have a strong voice in the choice for simple adoption. ${ }^{74}$ There is a strong sentiment that support should remain available after adoption for the foster child and the (adoptive) parents, ${ }^{75}$ and that a good relationship between the original parent(s) and the foster parents is a prerequisite for a successful simple adoption. ${ }^{76}$ Furthermore, a majority of the foster parents believes that they would need the foster care allowance to continue after simple adoption. ${ }^{77} \mathrm{~A}$ small majority of foster parents in the study believes that simple adoption should also be possible if the biological parents do not agree, as long as this is in the child's best interest. ${ }^{78}$ There is no consensus on how long a foster child must be in the care of the foster parents, before simple adoption should become possible, or on how old the child must be to have a say in this. A small majority believes that the adoption of adult foster children should be possible, but most do not believe that grandparents should be able to adopt their grandchildren. $^{79}$

\subsection{Simple adoption from the perspective of foster parents and foster children (in-depth interviews)}

In order to add more depth to the knowledge gained from the online questionnaires and to also include foster children in the study, a number of in-depth interviews were held with thirteen foster parents and eight foster children of varying ages. Recruitment of these participants took place through the questionnaire. ${ }^{80} \mathrm{In}$ total, 52 foster parents and 32 foster parent/foster child couples were willing to be interviewed. From this group, a selection was made based on region, age, and type of foster family in order to achieve as much representativity as possible. In order to include the experience of foster parents who had adopted their long-term foster child, three adoptive parents were approached through the network of the researchers.

73 The full questionnaire is available WODC Report 2020 in Bijlage 4.

74 WODC Report 2020, p. 86.

75 Ibid., p. 86.

76 Ibid., p. 86.

77 Ibid., p. 87-88.

78 Ibid., p. 89-90. The Committee also suggested this in their Report. Under current Dutch law parental consent is required for adoption (Art. 1:228 lid 1 sub d BW.) However, there are a limited number of circumstances under which a judge can dispense with parental consent (Art 1:228 lid 2 BW).

79 The adoption of adults is not allowed under Dutch law (Art. 1:228 lid 1 sub a BW) and neither is the adoption of a child by its grandparents (Art 1:228 lid 1 sub b BW). WODC Report 2020, p. 124, 125. 
The limited number of interviews, the diversity of backgrounds and the differences in situation of the participants, means that no clear answers can be derived from these interviews. Again, the opinions among the participants are divided and there is no consensus on the question whether simple adoption should be introduced. Foster parents who are in favour of simple adoption believe that it should only be possible with a number of prerequisites, such as the continuance of foster care support, and foster care allowance. ${ }^{81}$ Furthermore, some foster parents do not see a clear difference between simple adoption and foster parent guardianship and wonder whether simple adoption has any additional value. ${ }^{82}$ Foster parents who are not in favour of introducing simple adoption are either fundamentally against the adoption of foster children in general or say that simple adoption is a complicated and unclear intermediate form between foster parent guardianship and full adoption or believe that simple adoption is not suitable for their own situation. ${ }^{83}$ The most prevalent counterargument from the foster parents is that they would miss the help of an intermediary in the form of a youth care worker after simple adoption and that this may very well complicate the communication with the original parents. ${ }^{84}$

From the interviews with the foster children we can conclude that some of them are in favour of simple adoption, because they think it is a good solution for foster children who still have a good relationship with their original parents, but also want legal family ties with their foster family. ${ }^{85}$ Foster children who are not in favour of simple adoption say that they are afraid foster children would become stuck between their original parents and their foster parents, which would be very complicated. Other foster children said they were unable to judge how it would affect other foster children, since they only know their own situation. The points that foster children found most important are that, on the one hand, they want to have a say in decisions made about them and, on the other hand, that they wanted to be part of their foster family. There is no consensus among foster children for which groups simple adoption should be made available. A small majority of foster parents and most of the foster children think simple adoption should be possible for adults (ex-)foster children as well.

There is no consensus on the minimal duration of care before simple adoption should become possible. Some foster parents think a year is too short, while other foster parents think there should be no minimum duration of care, but instead whether or not simple adoption is an option it should depend on the perspective of the child, the child's developmental age and the circumstances of their specific case. The foster children also say that it should very much depend on the circumstances and the development of the child and some of them add that when children have been through a lot, they know much better what they want and are often un- 
derestimated in that respect. Others say that children need time discover what they want and that there should not be too much decision-making stress. Most foster parents and children do, however, agree that the opinion and best interests of the foster child should always be the most important factor in the decision-making process. Views on whether the original parents' consent is always required are less coherent. Some foster parents and children think that the consent of all parties is required, while others believe that as long as both the foster child and the foster parents really support the simple adoption, the view of the original parent(s) is not very important.

\subsection{Simple adoption from the perspective of professionals}

There is no clear answer as to whether the professionals who were interviewed $(\mathrm{N}=5)$ or who attended the expert meeting $(\mathrm{N}=4)$ are in favour of introducing simple adoption. ${ }^{86}$ According to some the legislator should look for other alternatives to strengthen the position of foster parents and thus solidify the position of the foster child in their care. Others believe simple adoption should be a possibility in the situations where this is the best solution for the foster child. Aside from this, the professionals believe that the advantages and disadvantages of simple adoption are strongly dependent on the conditions for and consequences of simple adoption. The professionals also indicate that an important advantage of simple adoption compared to full adoption is that the legal ties with the original parents and their family are maintained, protecting the child's original identity, while at the same time new ties are established with the foster parents and their family, even after the child turns eighteen. However, this can also be a disadvantage because this means that these three or four legal parents may have to cooperate closely, which can lead to conflicts, especially if the foster parents and the original parents have trouble communicating with each other.

Disadvantages of simple adoption compared to long-term foster care are mostly dependent on the decisions made on the (legal) consequences of simple adoption. The professionals primarily mentioned the end of the foster care allowance and foster care support. It is, however, possible to make certain (policy) decisions that will eliminate or lessen these disadvantages. If simple adoption were to be introduced, the professionals pointed to a number of other issues that need further elaboration: the education of foster care workers, the development of a decision matrix, the provision of aftercare/support and provision of financial assistance (foster care allowance, costs of the adoption process). Furthermore, the legal consequences of simple adoption for child maintenance obligations, custody/guardianship, inheritance rights and the surname(s) of the foster child should be made clear, since it is difficult to decide on the pros and cons of simple adoption if it is not entirely clear what it means for the parties involved.

The professionals believe that the consent of the foster parents is required for simple adoption and that the child must be heard, but there is no consensus as to whether the consent of the original parents should be a requirement and from 
what age foster children should be included in the decision-making process. There is also no consensus how long the child must have been in the care of its current foster parents before simple adoption should become possible. Furthermore, the professionals said that decisions have to be made about the simple adoption procedure (applicant(s), appropriate court, advisory persons/organs) and that other consequences of simple adoption, like nationality and migration rights, should be considered in depth. Lastly, if simple adoption were to be introduced, not only foster parents, but also others - like stepparents - might want to use this form of adoption to legally protect their family.

\section{Conclusion: Let us talk to Martha}

On the basis of this WODC research a clear yes or no to the question whether simple adoption should be made possible cannot be provided. Since there is great diversity among foster families and children and the maintenance of a connection with the original parent(s) and their family may be an advantage and a disadvantage of simple adoption at the same time, this does not come as a complete surprise. On the one hand, foster parents and professionals are concerned about possible conflicts between the original parents and the adoptive parents - the child could be caught between them - and, on the other hand, some regard the maintenance of legal ties with the original family as beneficial to the child. Furthermore, a number of foster parents indicate that they cannot manage without the foster care allowance and some form of support with maintaining contact with the child's original parents. What is very clear from the interviews with the foster children is that they want to have a say in decisions made about their future. Simple adoption can be regarded as a hybrid between the current options of foster parent guardianship (which gives the foster parents decision-making authority, but leaves the child's legal ties with the original family intact) and full adoption (which integrates the child fully in the adoptive family and severs legal ties with the child's original family). Simple adoption would leave the legal ties with the original family intact, but would also integrate the child fully in the adoptive family; the foster parents will obtain decision-making authority. When the child turns eighteen, it will remain part both of the original family and the adoptive family. Simple adoption may not be suitable for all foster children, which was also not the intention of the Committee's proposal, just like full adoption is not a good fit for every foster child. But broadening the long-term care options available for children who cannot grow up with their own parents may contribute to decisions that better fit the needs of the individual children.

On 17 December 2020 the government published its response to the study into the feasibility and desirability of the introduction of simple adoption. ${ }^{87}$ The Minister states that the government decided in July 2019 in its response ${ }^{88}$ to the earlier 
mentioned report by the Committee (Staatscommissie) not to introduce the possibility of multiparenthood. Since the simple adoption as described by the research in the report on simple adoption would mean the introduction of a form of multiparenthood, the Minister decided not to act. The Minister points out that the government intends to introduce a form of partial parental responsibility (deelgezag) for those carers who do not have a legal status but take care of a child nonetheless in conjunction with others who have the primary responsibility for the child. ${ }^{89}$ This could either take the shape of original parents having full parental responsibility and foster parents having partial parental responsibility, or the GI having full guardianship and the foster parents having partial guardianship. In itself this is an interesting idea since this would be a hybrid between full guardianship with the GI and full foster parent guardianship and it may solve a number of the (practical) problems encountered by foster parents. If simple adoption would also become possible, there will be a variety of options to choose from for children who cannot grow up with their original parents. However, on closer inspection, the partial parental responsibility/guardianship proposed by the government, is little more than an empty shell. Holders of partial parental responsibility will not be given any real rights such as the right to sign papers on behalf of the child (as is required for applying for a passport, opening a bank account or registering a child at school). Foster parents interviewed by the earlier mentioned Regioplan study indicated that these are the things they would value in partial guardianship. ${ }^{90}$ The problems mentioned by foster parents in the research discussed will therefore not be solved by this partial responsibility. Neither will it contribute to the recognition of the dual identity of the child as both being part of the original family and of the foster family which is also an element that is prominent in both studies (Regioplan and WODC). This may, however, not be the end of the discussion about simple adoption. On 25 February 2021 a motion was accepted by Parliament that more research into the benefits of simple adoption for long-term foster children from the perspective of foster children would be required. ${ }^{91}$ The motion suggests that interviewing long-term foster children who, like Martha and the others in the book mentioned earlier, have reached adulthood, may shed light on the needs of foster children in this context.

89 See Concept Wetsvoorstel Deelgezag (Wijziging van Boek 1 van het Burgerlijk Wetboek, de Jeugdwet en het Wetboek van Burgerlijke rechtsvordering in verband met de introductie van een regeling betreffende deelgezag over minderjarige kinderen door personen die in een nauwe persoonlijke betrekking tot het kind staan) - Consultatieversie en de bijbehorende Concept Memorie van Toelichting en Kamerstukken II 2019-2020, 33 836, nr. 54.

90 Regioplan 2015, p. 24-26.

91 Kamerstukken II 2020/2021 31265, nr. 90, Gewijzigde motie van de leden Bergkamp en Van den Berge over vervolgonderzoek naar voor- en nadelen van invoering van eenvoudige adoptie. 